2018

\title{
A Partial Magnetometer Survey of The Archaeological Conservancy's Portion of the A. C. Saunders Site (41AN19)
}

Dale Hudler

Jonathan Jarvis

Tim Griffith

Follow this and additional works at: https://scholarworks.sfasu.edu/ita

Part of the American Material Culture Commons, Archaeological Anthropology Commons, Environmental Studies Commons, Other American Studies Commons, Other Arts and Humanities Commons, Other History of Art, Architecture, and Archaeology Commons, and the United States History Commons

Tell us how this article helped you.

This Article is brought to you for free and open access by the Center for Regional Heritage Research at SFA ScholarWorks. It has been accepted for inclusion in Index of Texas Archaeology: Open Access Gray Literature from the Lone Star State by an authorized editor of SFA ScholarWorks. For more information, please contact cdsscholarworks@sfasu.edu. 


\section{A Partial Magnetometer Survey of The Archaeological Conservancy's Portion of the A. C. Saunders Site (41AN19) \\ Creative Commons License \\ (c) (1) (9)}

This work is licensed under a Creative Commons Attribution-NonCommercial 4.0 International License 


\title{
A Partial Magnetometer Survey of The Archaeological Conservancy's Portion of the A. C. Saunders Site (41AN19)
}

\author{
Dale Hudler, Jonathan Jarvis, and Tim Griffith
}

\begin{abstract}
Introduction
The Texas Archeological Research Laboratory (TARL) at The University of Texas at Austin conducted a partial magnetometer survey of The Archaeological Conservancy-owned portion of the A. C. Saunders site (41AN19) during the period between 6-8 December 2005. This survey was sponsored by the Texas Department of Transportation Environmental Affairs Division (TxDOT/ENV) due to a proposed expansion of the right-of-way of U.S. Highway 175 and was conducted under a research design approved by The Archeological Conservancy and TxDOT/ENV. The work was conducted under the direction of Dale Hudler (Principal Investigator) from TARL with a joint TARL/Prewitt and Associates, Inc. field crew (Jonathan Jarvis, TARL and Tim Griffith, Prewitt and Associates, Inc.).
\end{abstract}

\section{Methods}

\section{Site Grid}

The site grid was set using UTM coordinates (the method agreed to by TxDOT/ENV during project planning). Wooden stakes were driven in the northeast and southeast corners of the Conservancyowned portion of the site approximately $2 \mathrm{~m}$ inside the barbed wire fence bounding the property. A sub-meter GPS unit (Trimble AG-114) using datum WGS-84/grid UTM Zone 15N was used to locate both stakes (GPS readings shown in Figure 1). A total station was then set up over the southeastern stake and backsighted to the northeastern stake using the GPS locations as input (the total station showed an approximately $40 \mathrm{~cm}$ locational error on the backsight). The total station was then used to set collection area corners in the southern part of the site and a tape measure was used to run the baselines north and set the collection area corners in the north part of the site. The barbed wire fences running approximately North/South on the eastern and western boundaries of Conservancy property were found to diverge from UTM grid north approximately $2 \mathrm{~m}$ East/West per $100 \mathrm{~m}$ of North/South length, so the collection areas were offset by that amount as they were laid out. A total of seven collection areas were laid out and collected (Figure 2). The total area surveyed was 16,240 square meters.

\section{Magnetometer}

A Geometrics G-858 cesium magnetometer was used for data collection. A cart with dual sensors installed was pulled bi-directionally (with one exception noted later) on North/South transects located $1 \mathrm{~m}$ apart East/West. The sensors were located $50 \mathrm{~cm}$ apart on the cart ( $25 \mathrm{~cm}$ either side of centerline) providing a reading $25 \mathrm{~cm}$ either side of the transect line. The magnetometer was set to take readings every 0.1 second providing readings in each collection area at approximately $15 \mathrm{~cm}$ spacing North/South and $50 \mathrm{~cm}$ spacing East/West. A Geometrics G-856 proton magnetometer was operated as a base station to take magnetic background readings during G-858 collection. This collection method (two sensors to cover two lines rather than two sensors stacked vertically to provide magnetic gradients) has been demonstrated to provide equal or better results than the gradiometer configuration, and collection can be done more rapidly (Tabbagh 2003:75). The planned collection areas were walked prior to magnetometer collection to look for any metal objects on the ground that would affect collection. 


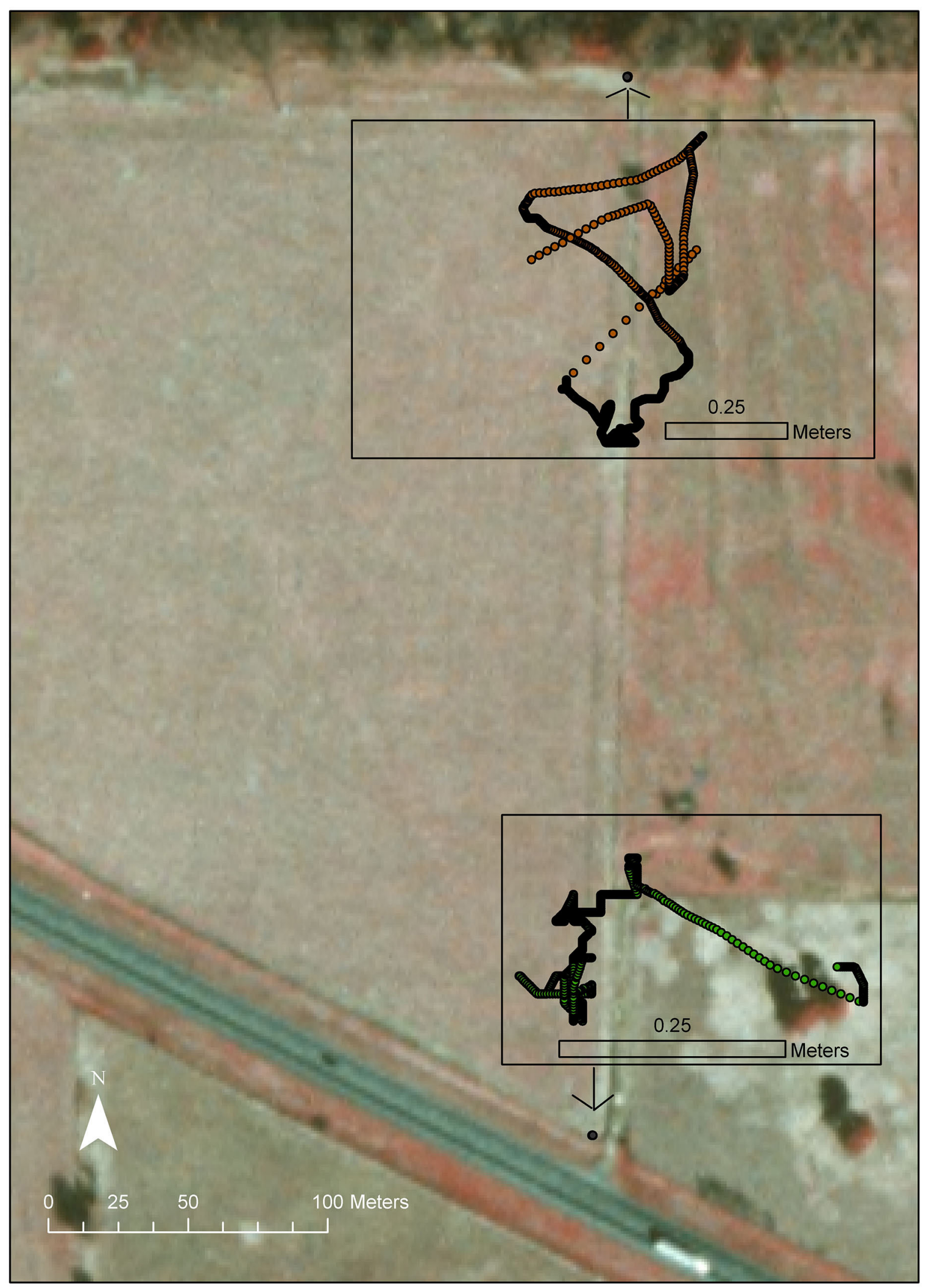

Figure 1. Temporary UTM grid datums and their locational accuracy. 


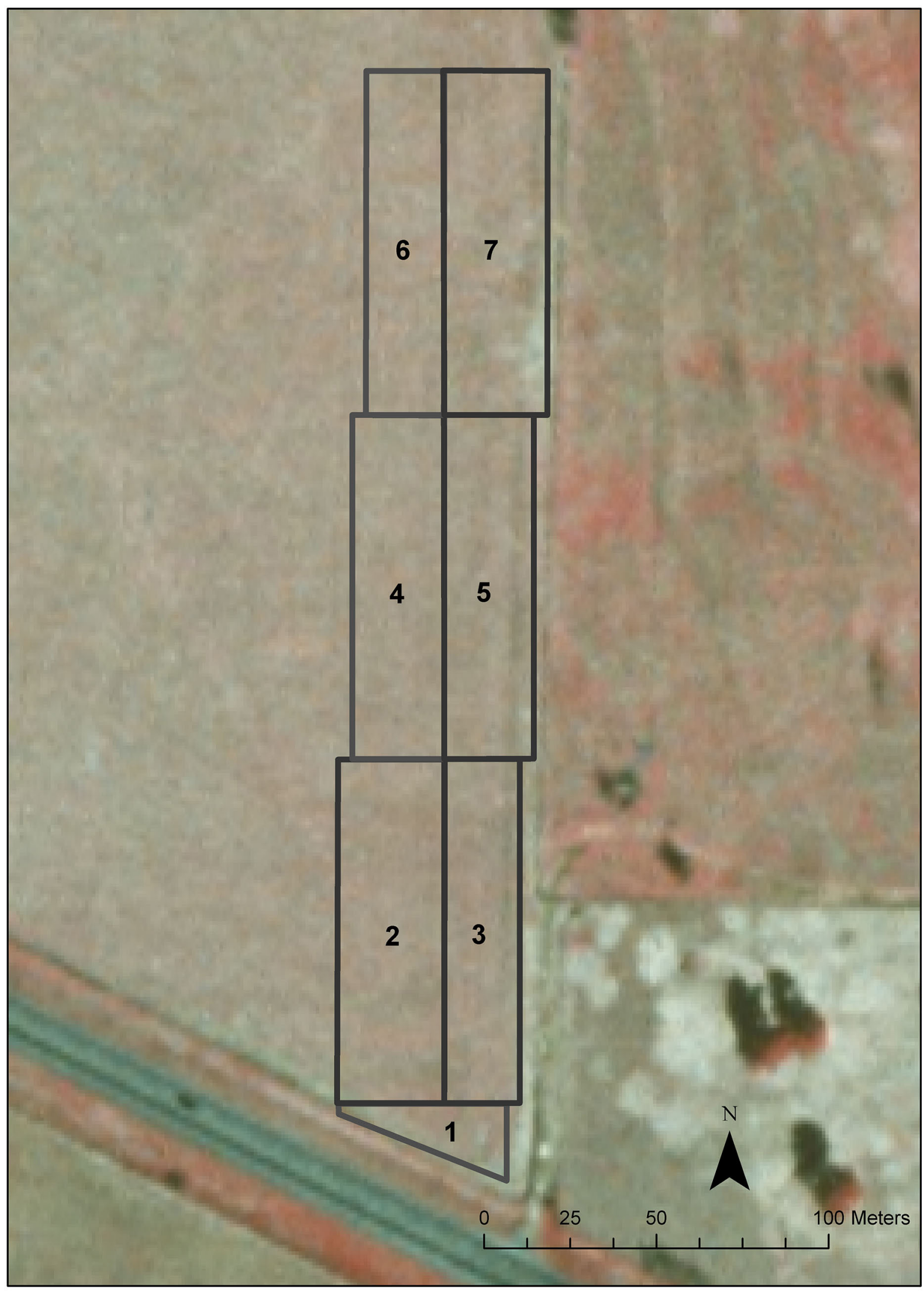

Figure 2. Magnetometer collection areas. 


\section{Processing}

The first step in processing the dataset was to subtract the base station readings from the cartmounted sensor readings to correct for variation in the general magnetic background during collection. The corrected sensor readings were then scanned and short-term very high/very low readings (spikes) and zero readings resulting from sensor 'dropout' were deleted using a Visual Basic for Applications (VBA) program written by the senior author. This program uses detection and evaluation methods described by Ciminale and Laddo (2001). Next the 'striping' effects caused by using dual sensors (exaggerated by pulling the sensor cart bi-directionally) were corrected for by processing the dataset through a VBA program (again written by the senior author). This program also was written using methods described by Ciminale and Laddo (2001). The resulting dataset was then imported into a GIS program (ArcGIS) and each collection area was gridded using a Kriging algorithm and linear model constrained to only consider readings within $1 \mathrm{~m}$ of the grid point being calculated. The resulting grids (displayed as a stretched gray-scale color ramp) are shown in Figure 3. Locations within the collection areas that have no grayscale displayed (blank) are the result of very high/low readings being deleted during despiking. As a last step, the ArcGIS grids were reprojected to datum NAD83/grid Zone $15 \mathrm{~N}$ for display on the $1 \mathrm{~m}$ Digital Orthogonal Quarter Quad (DOQQ) that covers the A. C. Saunders site area (Berryville SW).

\section{Results}

\section{Factors Affecting Results}

\section{Area 1 (triangle, 640 square meters)}

Collection in this area was degraded by the magnetic effect of the barbed wire fence bounding the southern edge of the site and by uneven towing speed. The metal in the fence produced a large induced magnetic field that shows in the collection as the low end of a dipole magnet (expressed as very dark areas along the southern edge of the grid display). These very low magnetic readings lower the sensitivity of the sensor for some distance beyond the dark areas depicted in the grid.

Because the sensors are more sensitive when lined up with the earth's magnetic field, the cart was towed on transects running North/South in all areas. In this area we backed the cart up to the fence (the sensors are near the rear of the cart) and then pulled it north on transects $1 \mathrm{~m}$ apart, making this the only collection area that was not towed bi-directionally. We backed the cart up to the vegetation along the fence to ensure that we caught the last of the fence dipole effect in the dataset. However, starting against the fence made it difficult to maintain a constant towing speed, particularly in the western part of the area where transects were very short. Holding a constant towing speed is important because the sensor controller designates reading locations along a track by dividing the total number of readings into the track distance and spacing the readings evenly along that distance. If reading locations become displaced far enough on adjacent transects the gridding process will generate linear features running North/South. Several of these can be seen in the western half of this collection area.

\section{Area $2(30 \times 100 \mathrm{~m}, 3000$ square meters $)$}

Collection in this area was very good. The dipole effect from the western boundary fence caused some very low readings to be removed from the northwest corner during despiking and low readings that remained after despiking are expressed as a dark area.

\section{Area $3(22 \times 100 \mathrm{~m}, 2200$ square meters)}

A large area of very low readings was caused by the fence projecting into the collection area at the entry gate. These readings were deleted during despiking and low readings that remained after despiking 


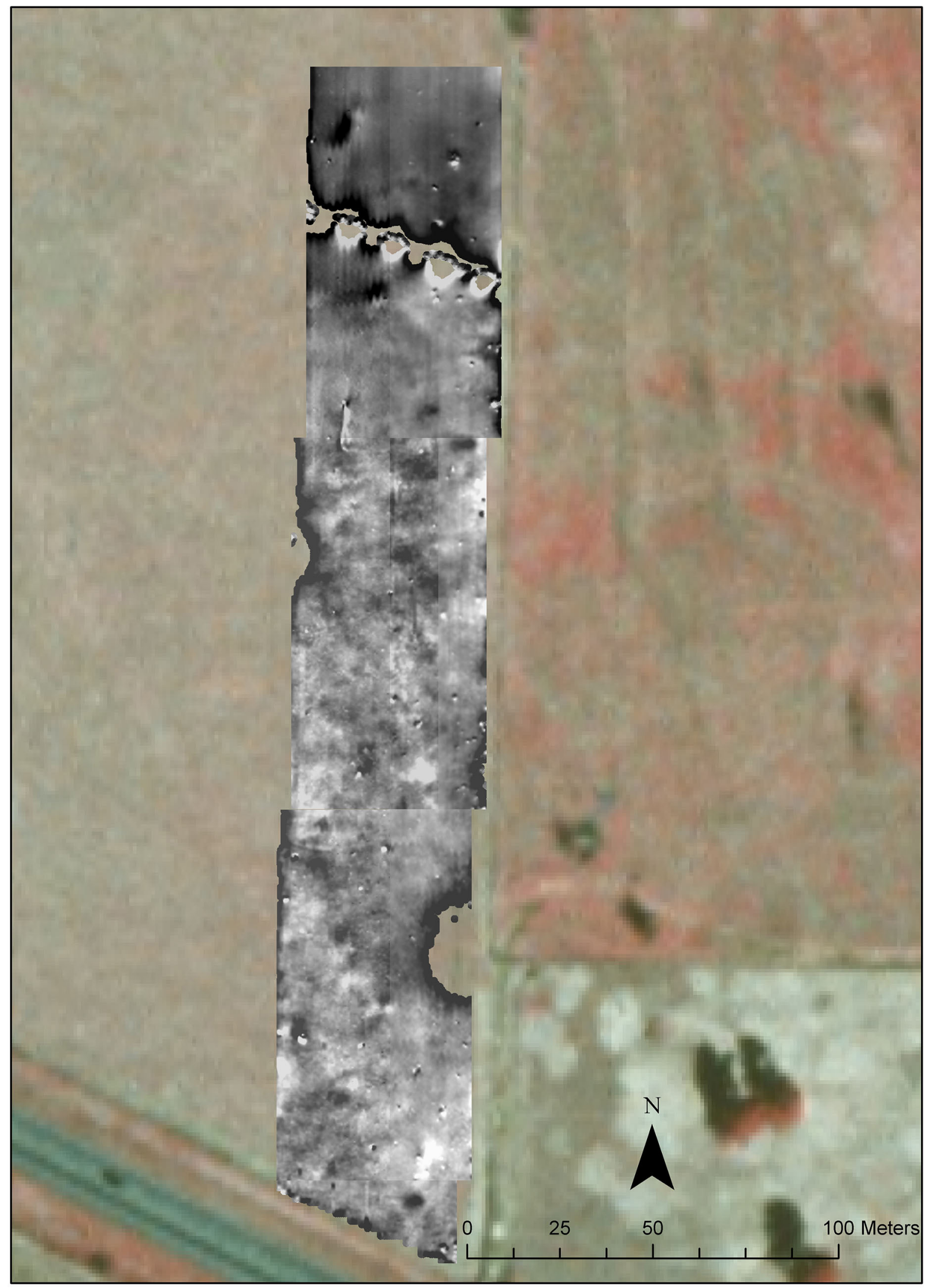

Figure 3. Magnetometer results shown as ArcGIS grids. 
are expressed as a dark area. Some zigzag effect can be seen in this collection area. This effect was probably caused by parallax error as the operator looked back at the cart to determine when the sensors were exactly over the mark points. This parallax error creates a problem in bidirectional towing, as the readings are displaced in different directions on adjacent lines.

\section{Area 4 (26 x 100 m, or 2600 square meters)}

There is some slight North/South striping in this area, possibly from towing speed errors, but possibly due to application of the destriping program (if despiking is not rigorous enough, the destriping routine tends to average the spike readings down the entire collection line). Two tall metal birdhouse poles on the western boundary fence caused an area of very low readings that were deleted during despiking. A small area in the northwest corner was affected by the western boundary fence.

\section{Area $5(26 \times 100 \mathrm{~m}, 2600$ square meters)}

The system gave a battery low warning half way through collecting this area so we paused to change batteries. The power supply change caused a slight change in readings in the remainder (eastern half) of the collection area which can be seen as a change in the gray scale shading between the two halves. There is a North/South stripe in the middle of the western half caused by the operator tripping on a rope used as a $10 \mathrm{~m}$ mark. The change in speed and sensor rotation (caused by cart handle movement) resulted in a mismatch in readings between adjacent transects. The eastern half of the collection area has light striping, probably due to the processing algorithm (more stringent despiking might have eliminated these stripes). The eastern boundary fence affected collection in the southeastern corner of the area.

\section{Area $6(22 \times 100 \mathrm{~m}, 2200$ square meters $)$}

A zig zag effect can be seen in this area, probably due to parallax error when crossing marked positions. A buried pipeline caused the large dipole readings crossing the area in an East/West direction. The highest/lowest readings were eliminated during despiking. The western boundary fence affected collection in the northwestern corner.

\section{Area $7(30 \times 100$ m, 3000 square meters)}

A buried pipeline caused the large dipole readings crossing the area. The highest/lowest readings were eliminated during despiking. The eastern boundary fence slightly affected collection in the southeastern corner.

\section{Magnetic Anomalies Noted}

\section{Circular Anomalies}

Magnetic feature 1 (Figure 4) is centered at grid coordinates E269159 N3547864. It consists of a dipole signature in the center (possible hearth) surrounded by a circular arc of lower magnetic values approximately $19 \mathrm{~m}$ in diameter.

Magnetic feature 2 (Figure 5) is centered at grid coordinates E269155 N3547890. It consists of a very faint dipole signature in the center (possible hearth) surrounded by a partial circular arc of lower magnetic values approximately $17 \mathrm{~m}$ in diameter.

Magnetic feature 3 (Figure 6) is centered at grid coordinates E269162 N3547905. It consists of a partial circular arc of lower magnetic values that is approximately $20 \mathrm{~m}$ in diameter. 


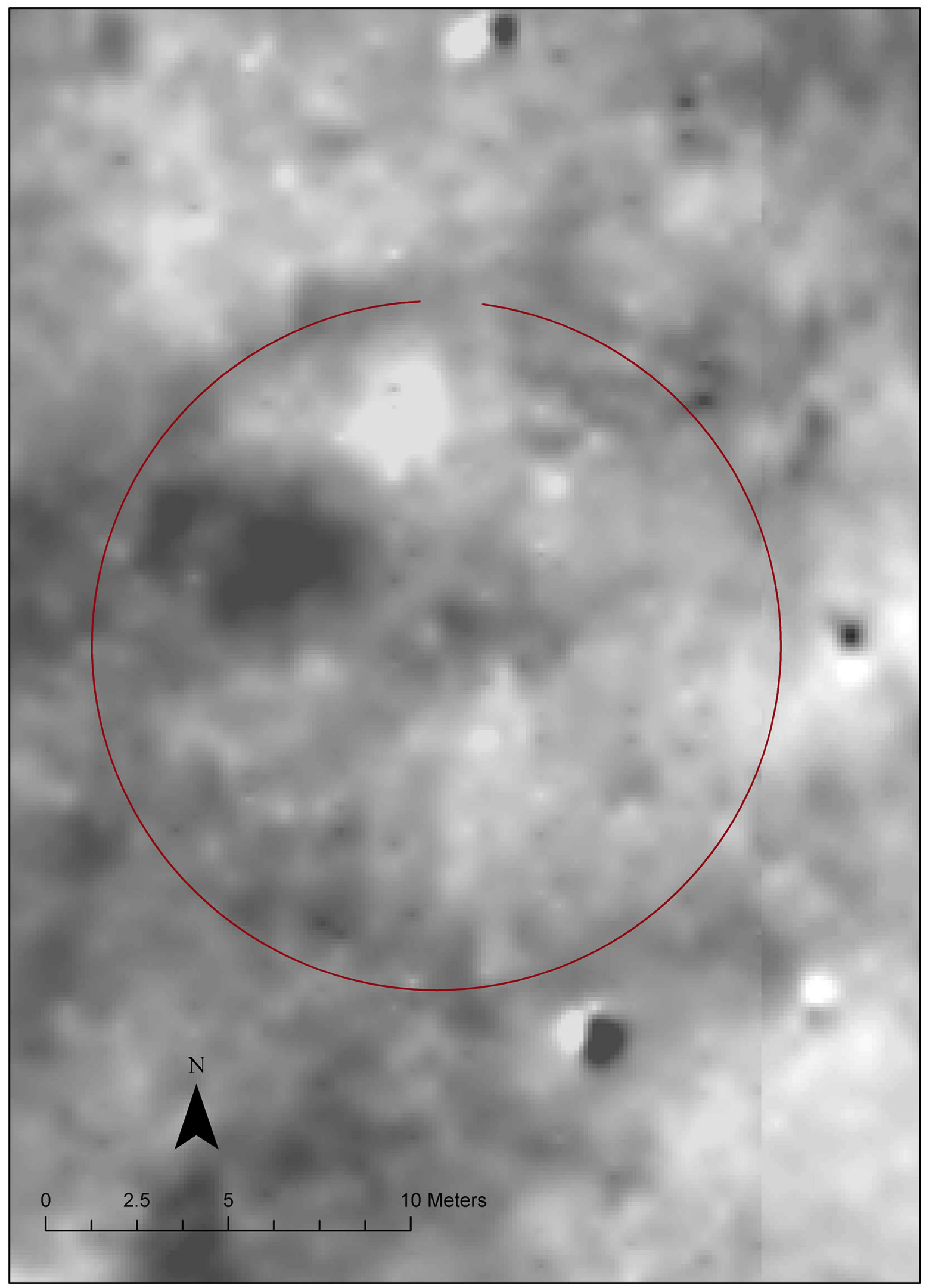

Figure 4. Magnetic feature 1: possible ring of postholes. 




Figure 5. Magnetic feature 2: possible ring of postholes. 


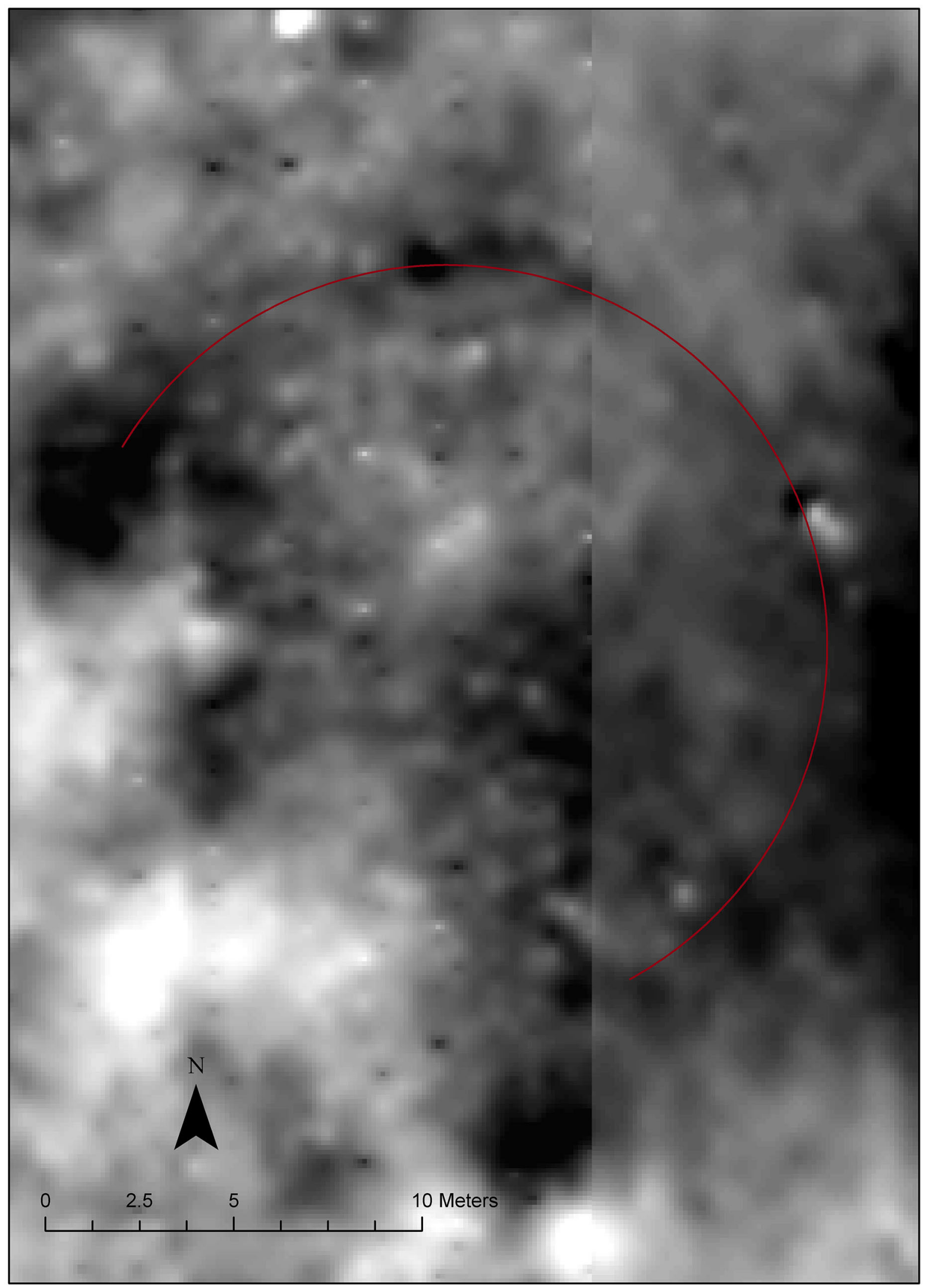

Figure 6. Magnetic feature 3: possible ring of postholes. 
Magnetic feature 4 (Figure 7, shown in hill-shaded display) is centered at grid coordinates E269156 N3548076. It consists of a faint dipole signature in the center of a circular pattern of low magnetic readings that is approximately $13.5 \mathrm{~m}$ in diameter.

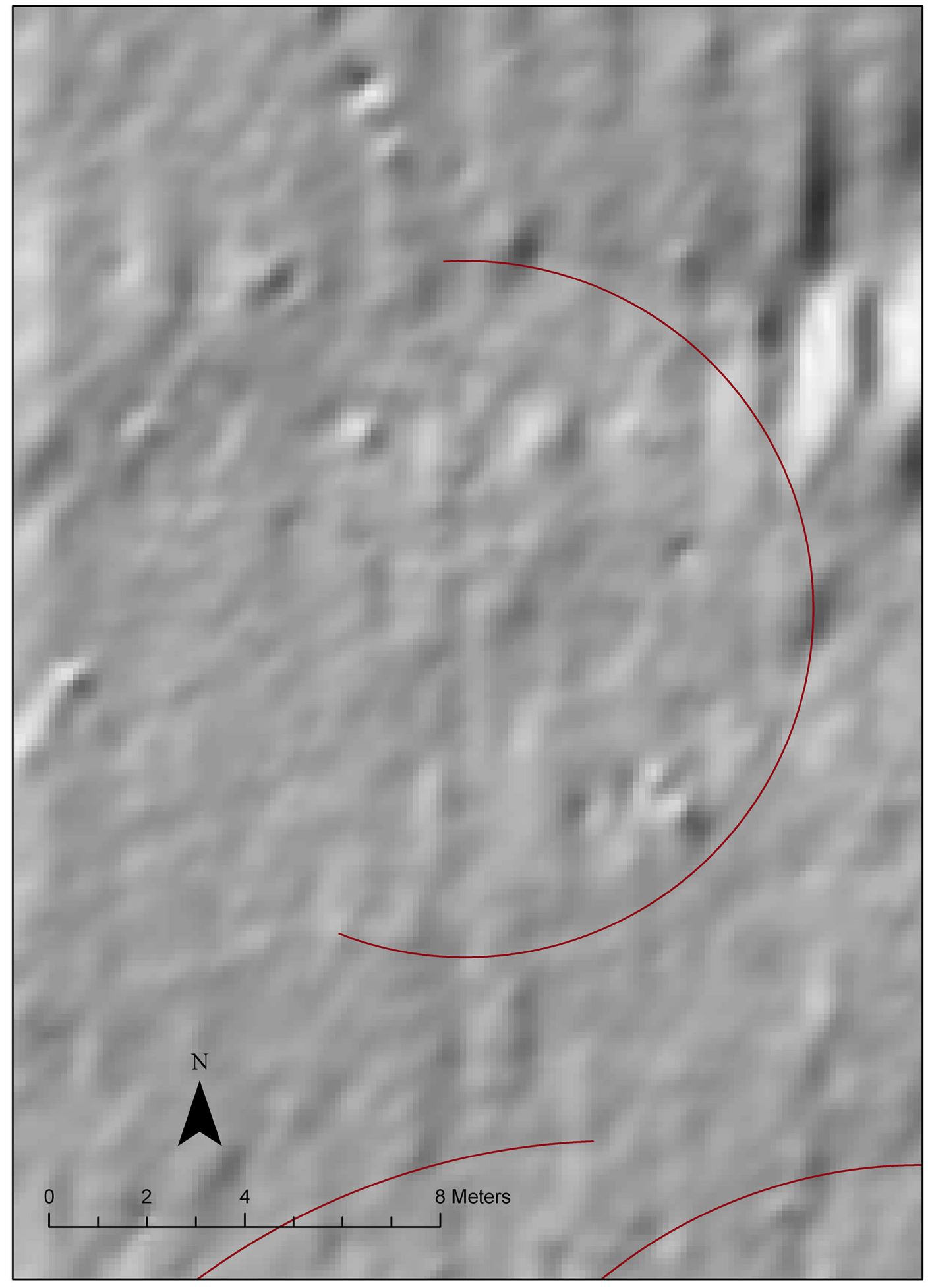

Figure 7. Magnetic feature 4: possible ring of postholes. 


\section{Short Arcs of Low Magnetic Readings:}

Magnetic feature 5 (Figure 8) is centered at grid coordinates E269153 N3548064.

Magnetic feature 6 (see Figure 8) is centered at grid coordinates E269162 N3548065.

Magnetic feature 7 (see Figure 8) is centered at grid coordinates E269149 N3548058.



Figure 8. Magnetic features 5, 6, and 7: possible arcs of postholes. 
Magnetic feature 8 (Figure 9) is centered at grid coordinates E269143 N3547899.

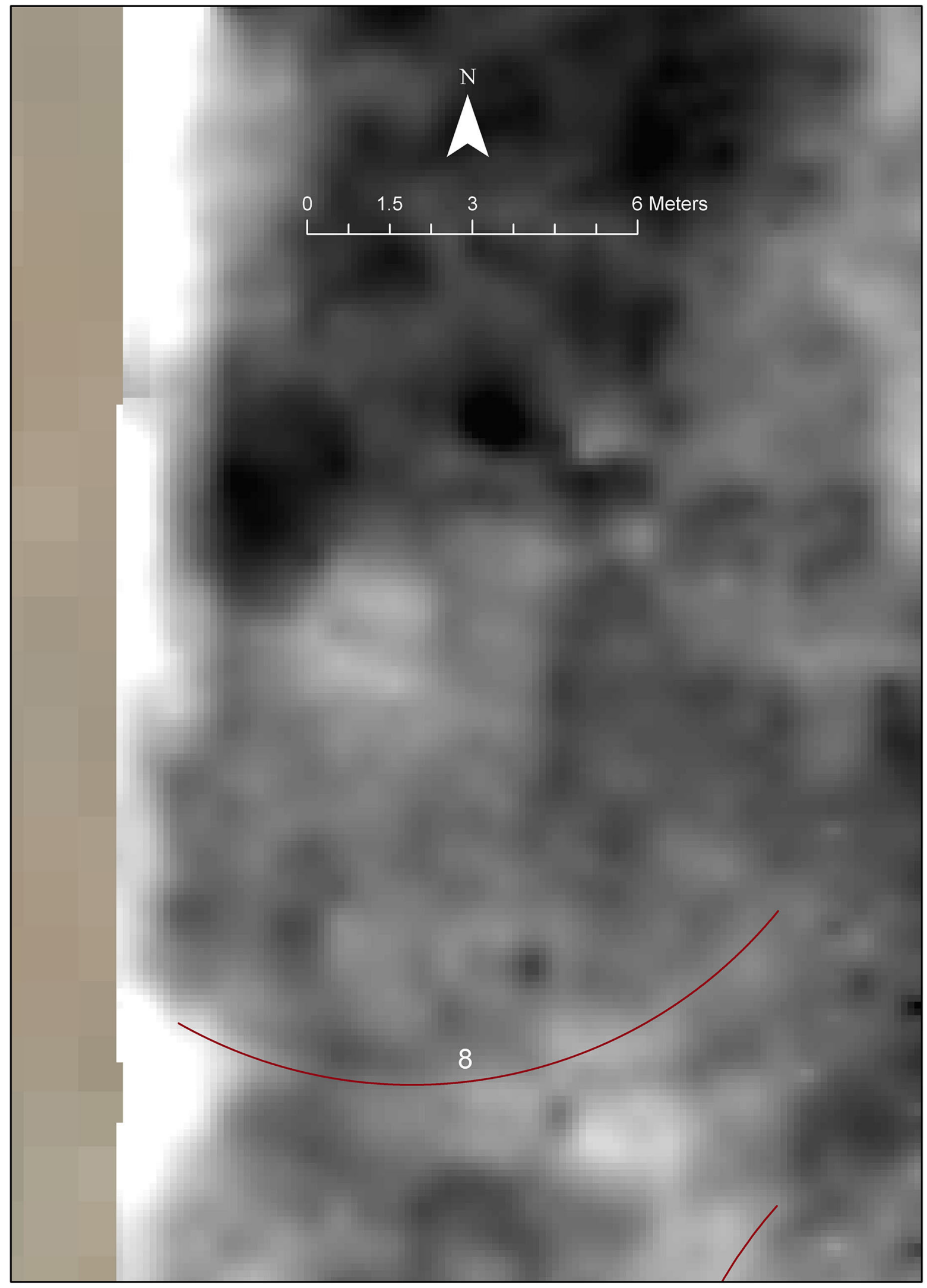

Figure 9. Magnetic feature 8: possible arc of postholes. 


\section{Rectangular Areas of Low Magnetic Readings}

Four rectangular-shaped areas of low magnetic readings (Figure 10) that are generally the same size (approximately $1.8 \mathrm{~m} \mathrm{~N} / \mathrm{S}$ by $1 \mathrm{~m} \mathrm{E} / \mathrm{W}$ ) can be seen centered at grid coordinates E269152 N3547842.5 (Magnetic feature 12), E269143 N3547846 (Magnetic feature 13), E269155 N3547873 (Magnetic feature 14), and E269149.5 N3547880 (Magnetic feature 15). These features may be weak dipoles as several show readings slightly higher than the magnetic background on their north sides.

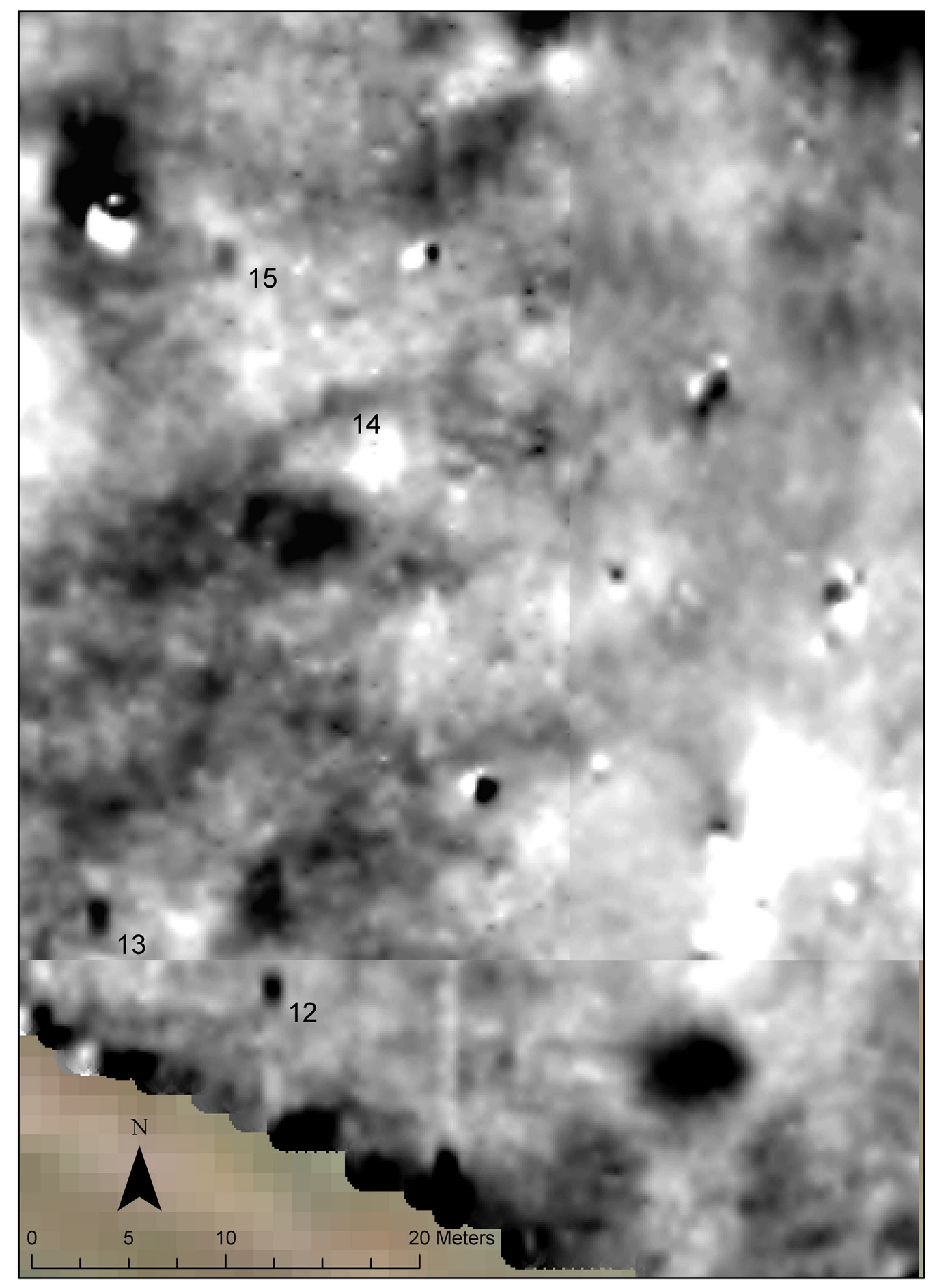

Figure 10. Magnetic features 12-15: rectangular-shaped areas of low magnetic readings. 


\section{Linear Patterns of Low Magnetic Readings}

Linear patterns of low magnetic readings are centered at E269191 N3548069 (Magnetic feature 16, Figure 11) and E269146 N3547937 (Magnetic feature 17, Figure 12). Linear patterns of lower magnetic readings that generally form the outline of a rectangle are centered at grid coordinates E269170 N3547839 (Magnetic feature 18, Figure 13, shown in hill-shaded display).

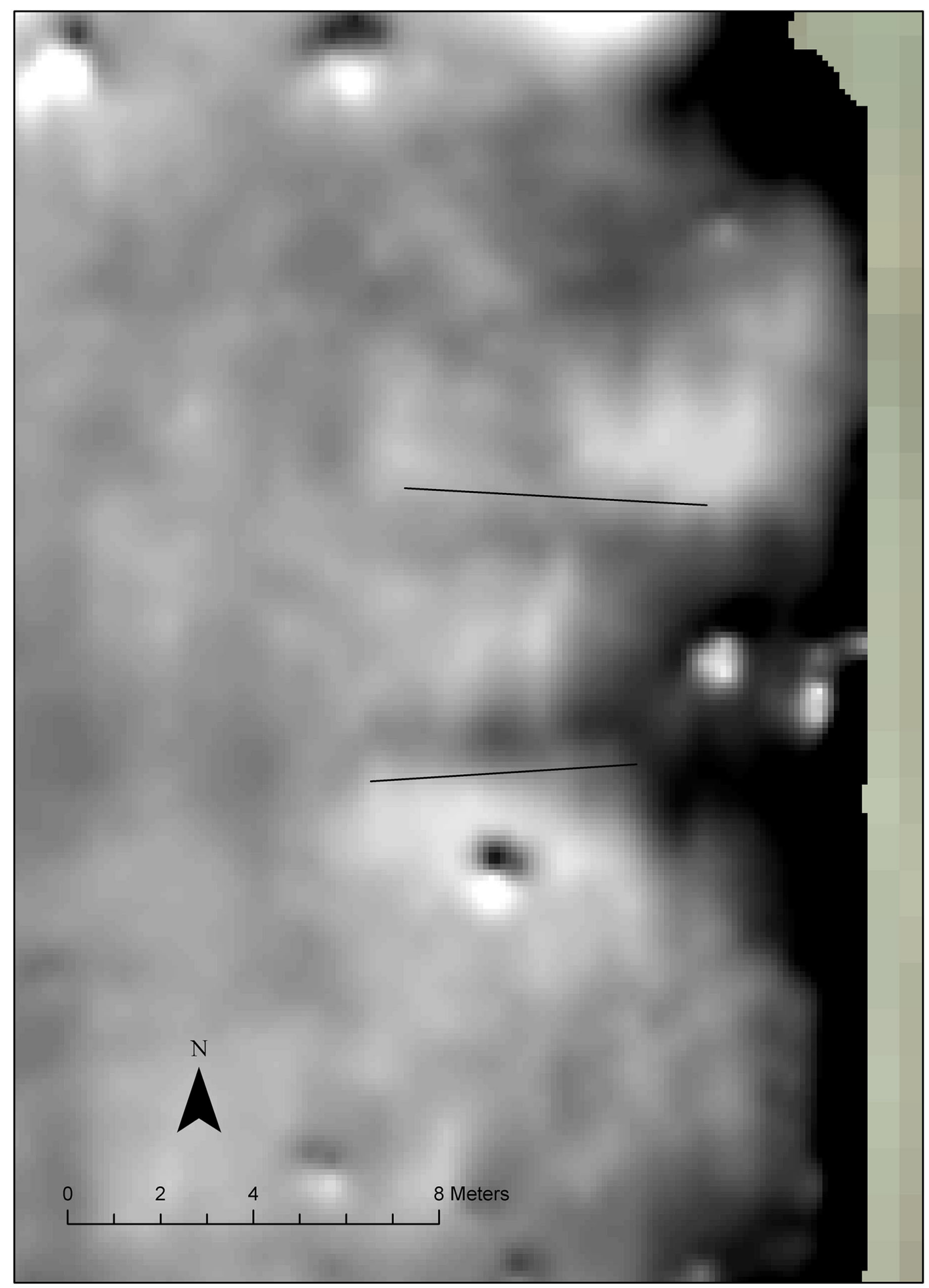

Figure 11. Magnetic feature 16: possible undocumented trenches into the "ash" mound. 


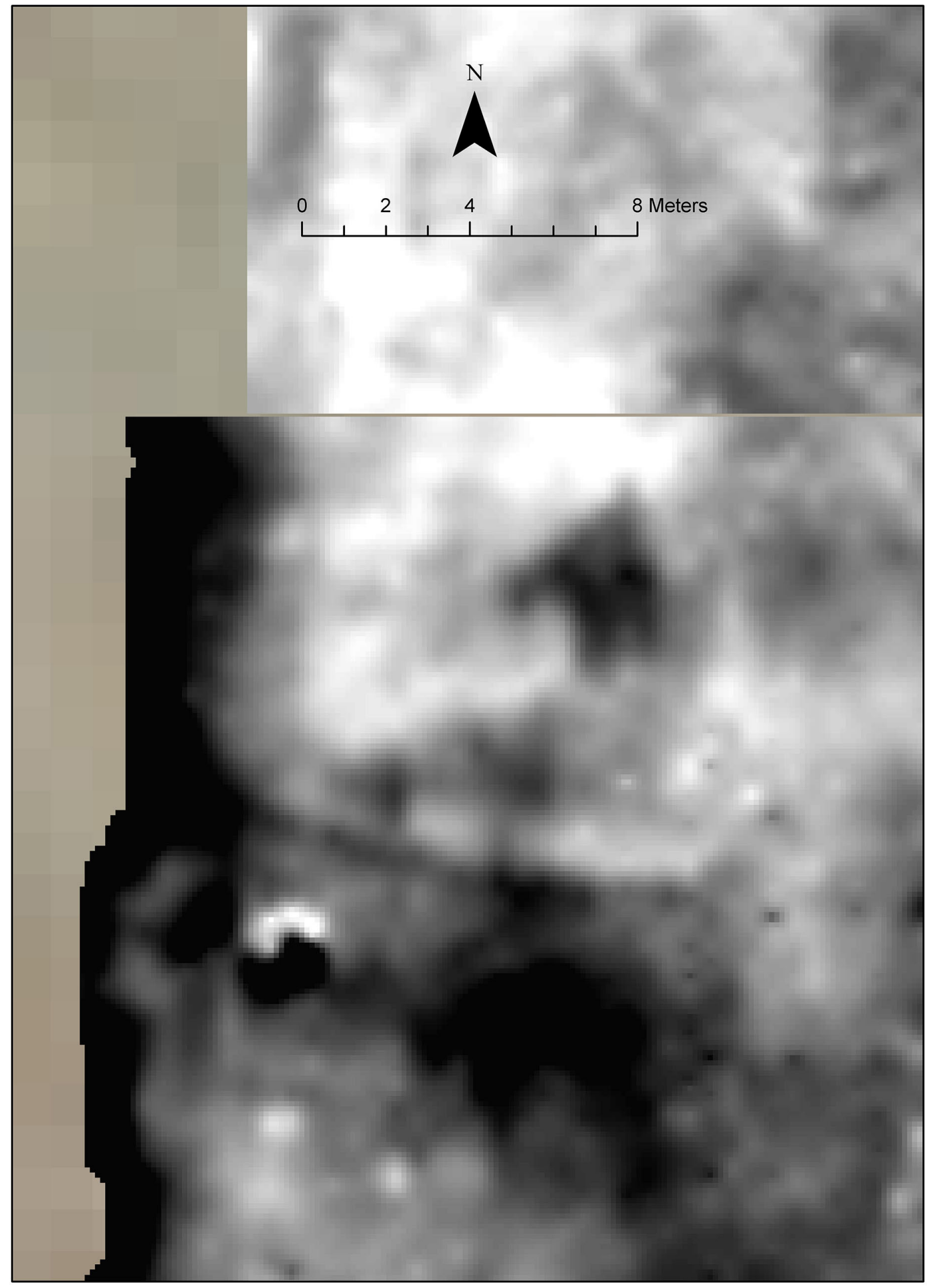

Figure 12. Magnetic feature 17: linear pattern of low magnetic readings. 


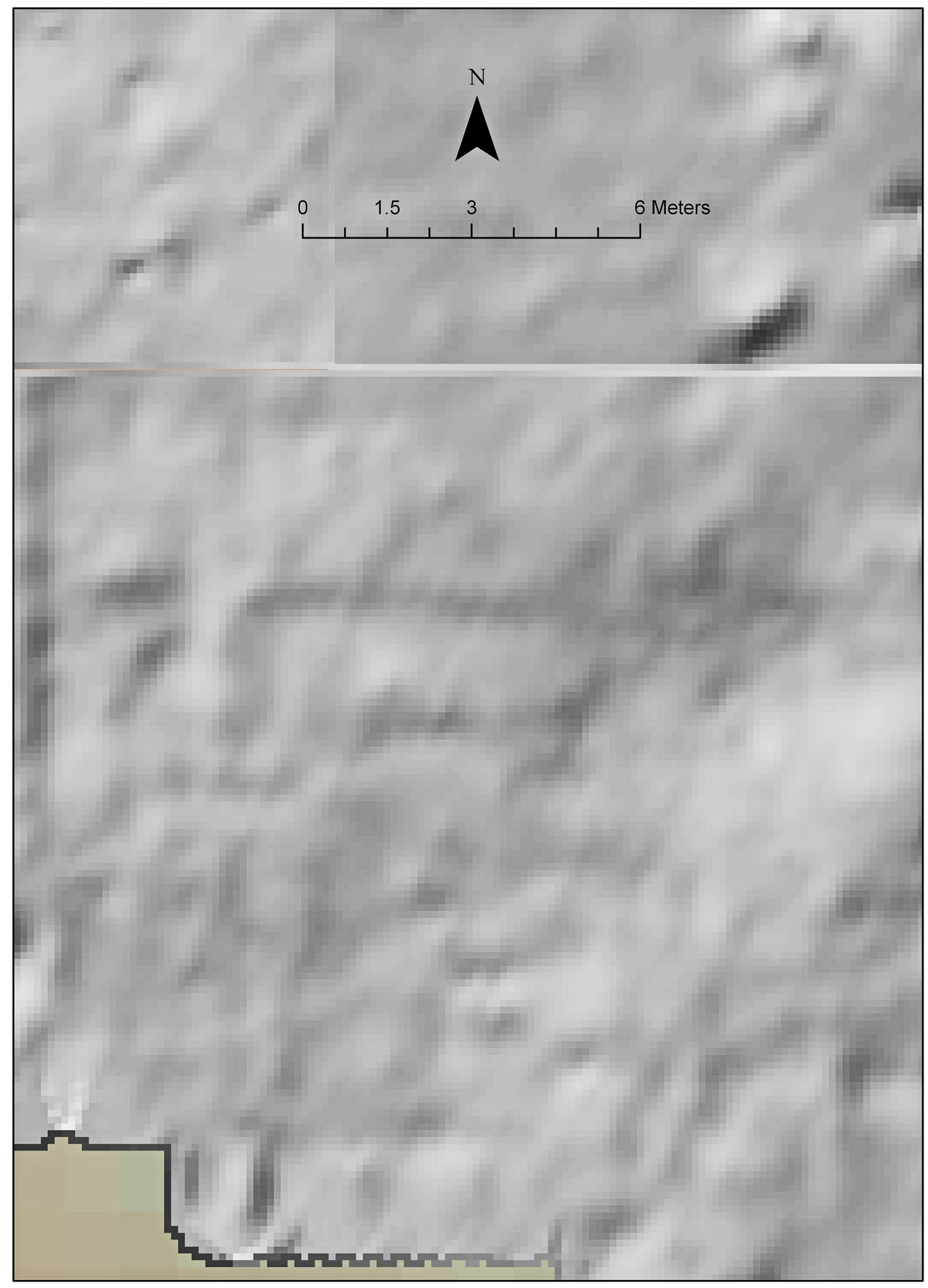

Figure 13. Magnetic feature 18: linear pattern of low readings that generally form a rectangle. 


\section{Interpretation}

\section{Previous Archaeological Work at the Saunders Site}

The A. C. Saunders site was first excavated in 1931 by A. T. Jackson, who tested part of the low mound and a midden on the site and recorded the results in an in-house (University of Texas) report summarizing his Anderson County excavations for 1931. In 1933 E.B. Sayles also put a test pit into the midden and generated a site survey form that is archived at TARL. In 1935 A.T. Jackson returned to the site and trenched the 'Ash Mound' and completely removed the remaining part of the midden. A circular pattern of postholes approximately $13 \mathrm{~m}$ in diameter was found below the midden. Figure 14 is Jackson's 1935 drawing of this feature. Jackson's notes and photos from these excavations are on file at TARL and Jackson published a report in 1936 (Jackson 1936). Jackson's field map of his 1935 excavations is shown at Figure 15, and the approximate locations of these excavations are shown on the DOQQ in Figure 16. A student from the University of Texas (Ulrich Kleinschmidt) revisited the site in 1978 and 1981 and completed a surface survey to accompany his re-analysis of the site artifacts housed at TARL (Kleinschmidt 1982). Kleinschmidt's map of the A. C. Saunders site is shown at Figure 17.

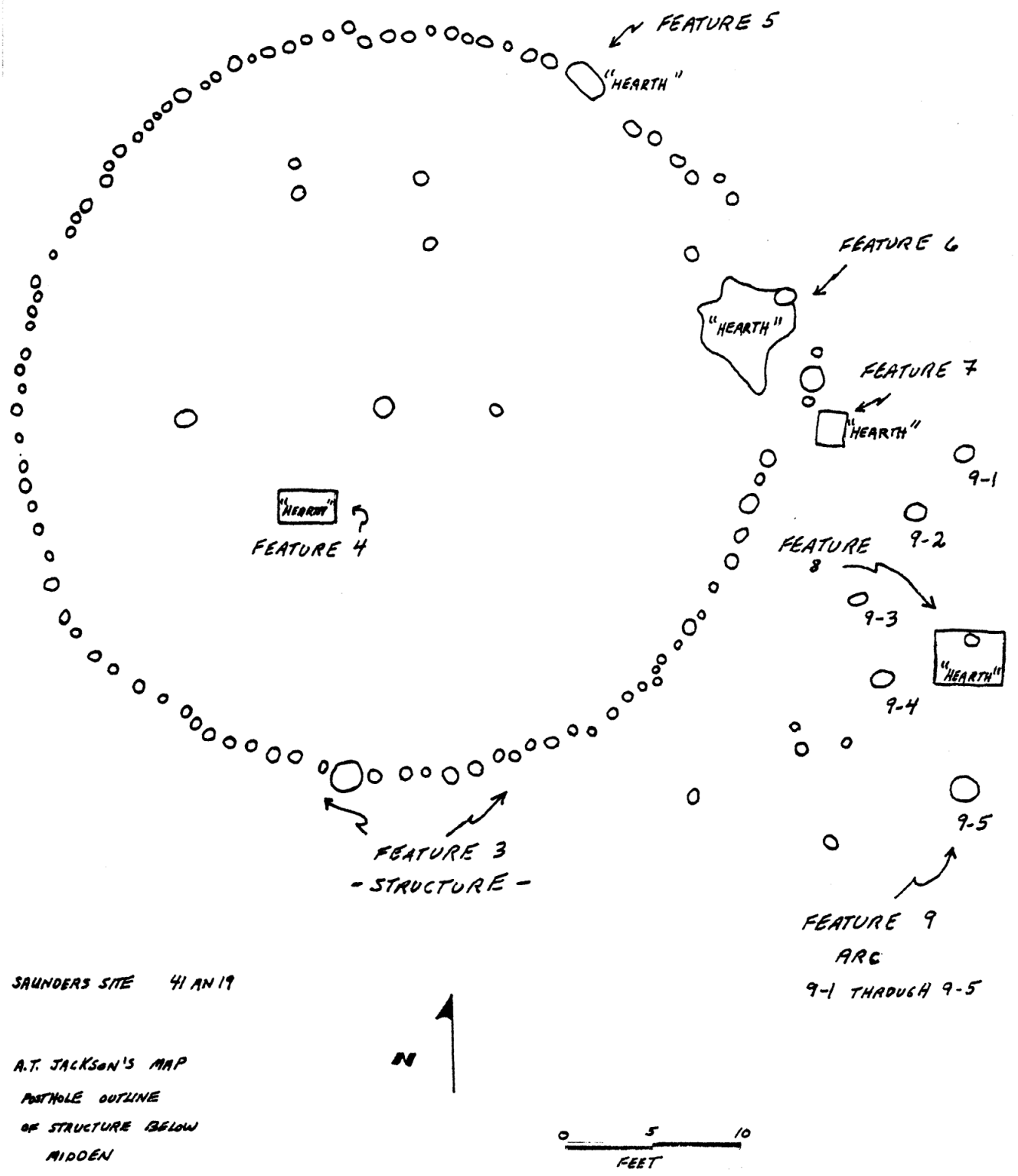

Figure 14. A. T. Jackson's 1935 drawing of a ring of postholes found below the midden he excavated. 


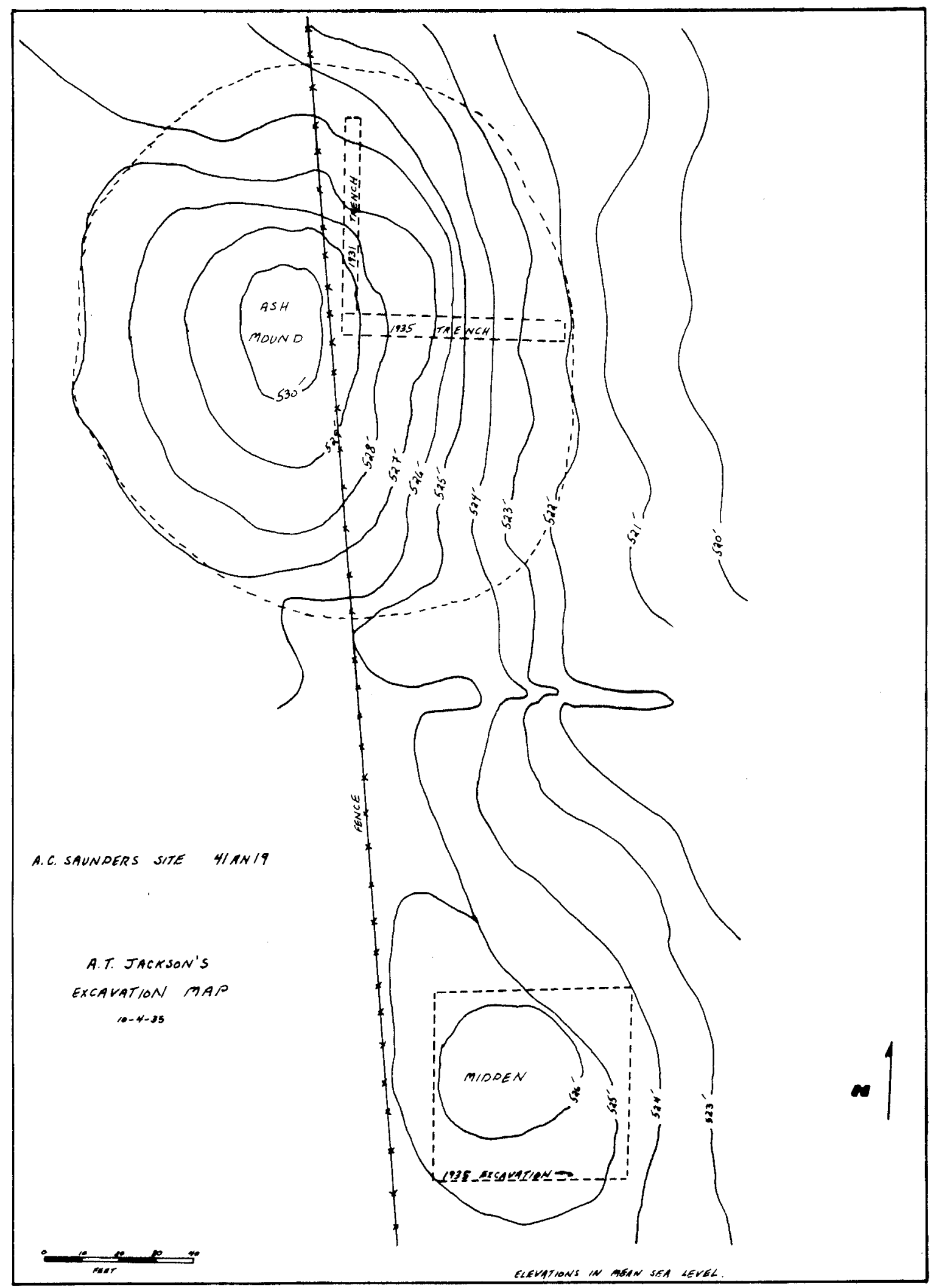

Figure 15. A. T. Jackson's field map of his 1935 excavations. 


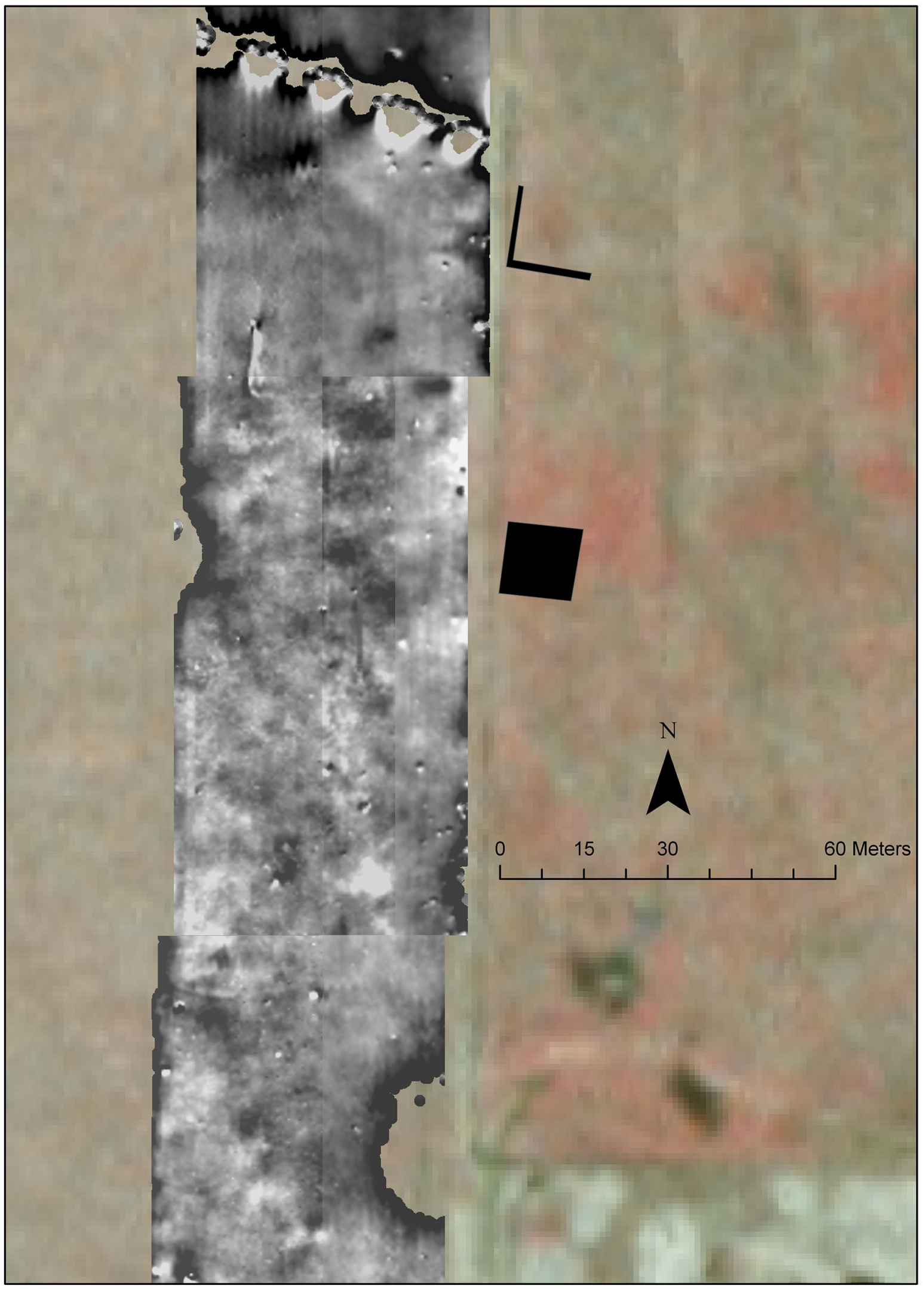

Figure 16. Approximate locations of A.T. Jackson's 1935 excavations. 


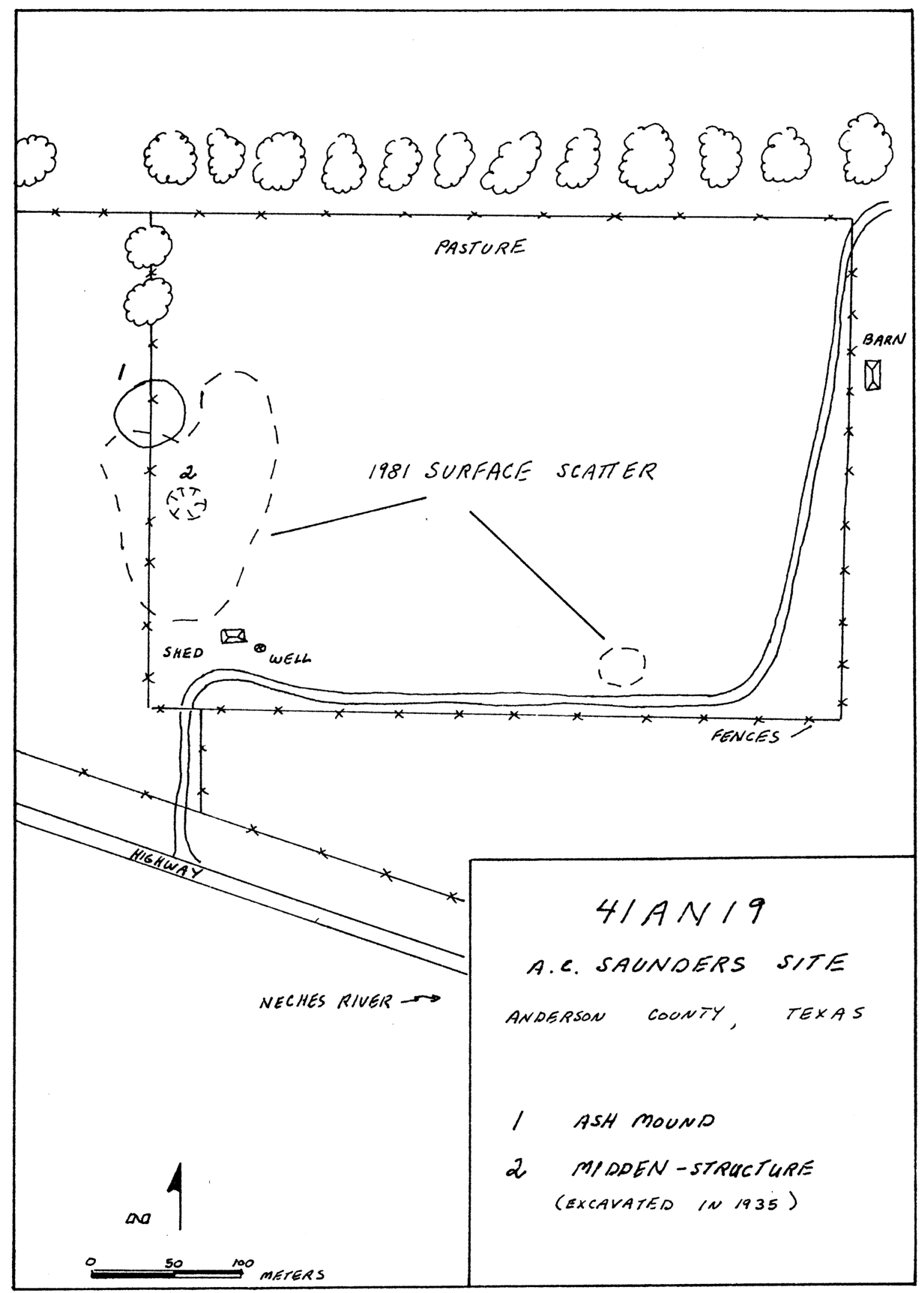

Figure 17. Kleinschmidt's 1982 map of the A. C. Saunders site. 


\section{Magnetometer Survey at the George C. Davis Site (41CE19)}

A magnetometer survey has been conducted at the George C. Davis site (Creel et.al. 2005), a Caddo site in the same river basin and that has a clay matrix similar to the A. C. Saunders site. Postholes in the George C. Davis survey were found to be less magnetic than the surrounding matrix and unambiguous circular patterns of postholes were found that were 19 to $20 \mathrm{~m}$ in diameter (Figure 18).

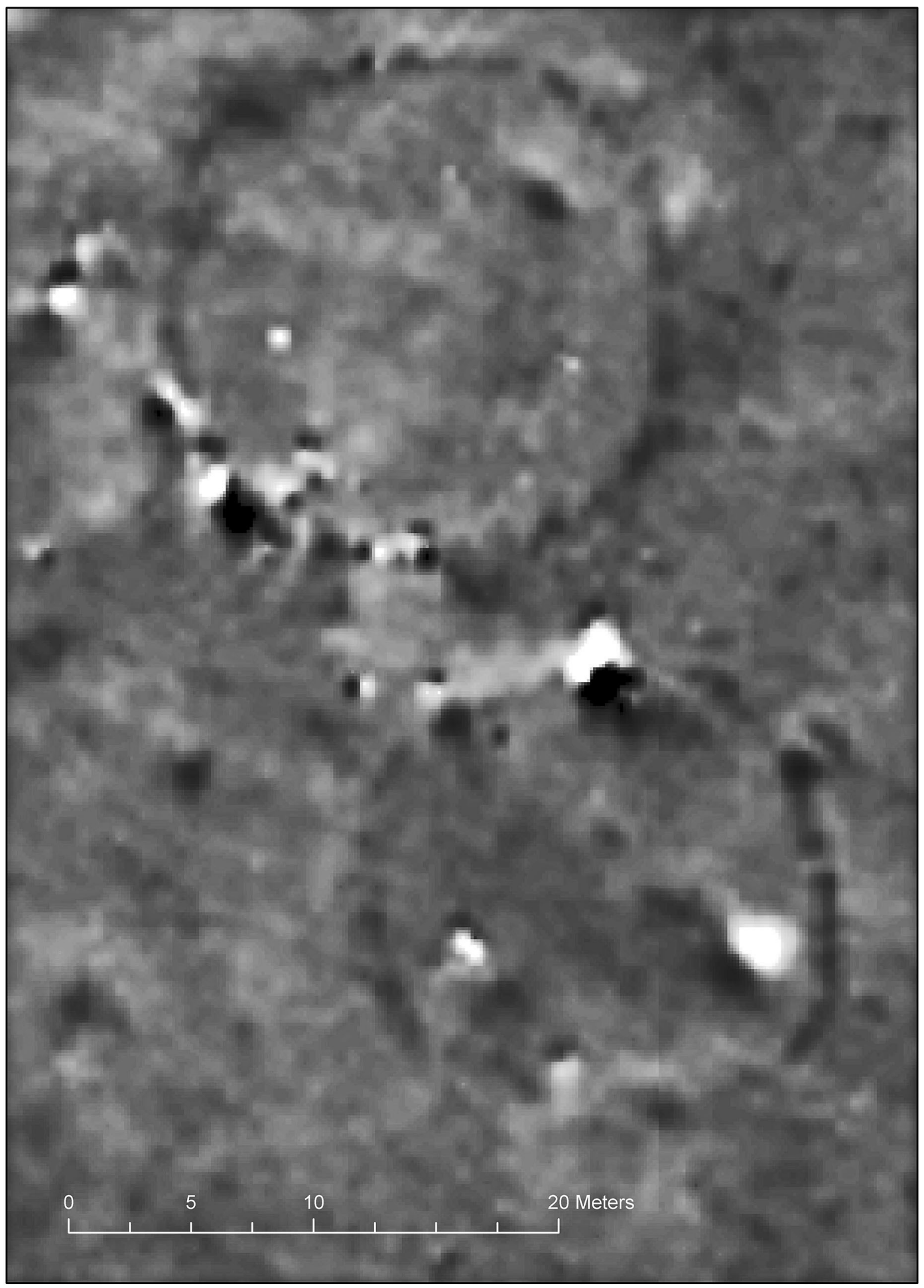

Figure 18. Magnetic features at the George C. Davis site interpreted as rings of postholes. 


\section{Interpretation of the A. C. Saunders Site Magnetic Anomalies}

Although they are much less distinct, the circular features and arcs at the A. C. Saunders site (Magnetic features 1-8) could well be circles (and partial remnants of circles) of postholes similar to those seen much more clearly expressed at the George C. Davis site and known to have existed at the A. C. Saunders site from Jackson's excavations. In particular, Magnetic features 1, 2, and 4 are very similar to the George C. Davis site magnetic features in that they have dipole signatures in their centers.

The rectangular features (Magnetic features 12-15) do not resemble any magnetic feature seen at the George C. Davis site, but possibly they represent square-shaped disturbances (holes, excavations?) in the original matrix of the site. Linear Magnetic feature 16 appears to represent two trenches into the western part of the 'Ash Mound,' although there are no recorded excavations into this side of the mound by either Jackson or Sayles.

\section{Proposed TxDOT Right-of-Way}

The portion of the magnetometer survey that covers the proposed expansion of the TxDOT ROW is shown in Figure 19. This area includes Magnetic feature 1 (possible circular structure) and three of the four rectangular features (Magnetic features 12, 13, and 14).

\section{References Cited}

Ciminale, M. and M. Loddo

2001 Aspects of Magnetic Data Processing. Archaeological Prospection 8:239-246.

Creel, D., D. Hudler, S. Wilson, C. Schultz, and C. Walker

2005 A Magnetometer Survey of Caddoan Mounds State Historic Site. Technical Report 51. Texas Archeological Research Laboratory, The University of Texas at Austin.

Jackson, A. T.

1936 A 'Perpetual Fire' Site. Bulletin of the Texas Archeological and Paleontological Society 8:134-173.

Kleinschmidt, U. K. W.

1982 Review and Analysis of the A. C. Saunders Site. Master's thesis. Department of Anthropology, The University of Texas at Austin

Tabbagh, J.

2003 Total Field Magnetic Prospection: Are Vertical Gradiometer Measurements Preferable to Single Sensor Survey? Archaeological Prospection 10:75-81. 


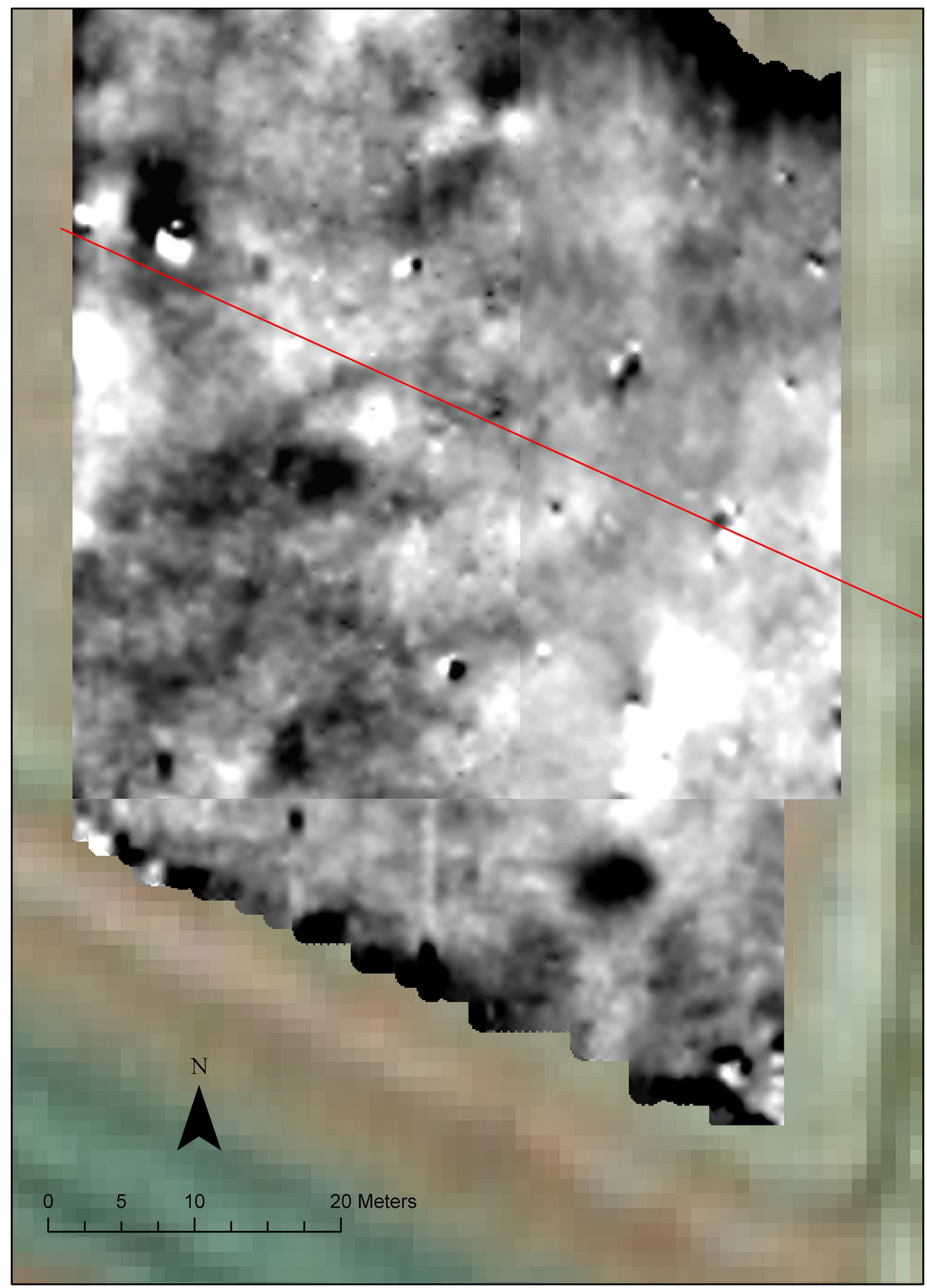

Figure 19. Section of the magnetometer survey that is in the proposed expansion of US Highway 175 right-of-way. 